\title{
THE LINK BETWEEN BANK CREDIT AND PRIVATE SECTOR INVESTMENT IN NIGERIA FROM 1980-2014
}

\author{
Ephraim Ugwu ${ }^{1 *}$, Johnson $\mathrm{Okoh}^{2}$, Stella Mbah ${ }^{3}$ \\ ${ }^{1}$ Department of Economics and Development Studies, Faculty of Social Sciences, Federal \\ University, Oye-Ekiti, Ekiti State, Nigeria. \\ ${ }^{2}$ Department of Banking and Finance, National Open University of Nigeria, Lagos State, \\ Nigeria. \\ ${ }^{3}$ Department of Economics and Development Studies, Faculty of Social Sciences, Federal \\ University, Oye-Ekiti, Ekiti State, Nigeria. \\ ephraim.ugwu@fuove.edu.ng \\ okohjohnson1@gmail.com \\ stella.mbah@fuove.edu.ng
}

\begin{abstract}
This study attempts to investigate the link between bank credit and private sector investment in Nigeria from 1980 to 2014 using Ordinary Least Square (OLS) regression procedure. The study also employs other preliminary investigations which include, unit root, cointegration and Granger causality test procedures. The OLS result indicates that the coefficients of the variables which include, banks credit to the private sector (CRPRIVAT), trade openness (OPEN), exchange rate (EXCHR) and total bank saving (BSAVING) exhibit positive signs to the dependent variable, private investment (INVEST) during the period under review, while the coefficients of two other variables, capital expenditure (CAP) and interest rate (INTR) indicate negative signs to the dependent variable. The stationarity test result shows that all the variables under consideration are stationary and integrated of order one at 5\% significance level. Also, the cointegration test result indicates at most five cointegrating equations at $5 \%$ level of significance. The Granger causality test result shows that a bi-directional causality exists between banks credit and private investment and also between private investment and capital expenditure, while a uni-directional causality exists from exchange rate to private investment.Statistically, the descriptive statistics result indicates that all the variables have a positive mean values which ranges from 18.05390 to 2427052 with 34 observations. The correlation test result obtained shows that four variables, CRPRIVAT, OPEN, EXCHR and BSAVING have positive relationships with the dependent variable INVEST. The $t$-statistic result shows that five of the variables which includes, CRPRIVAT, OPEN, CAP, INTR and EXCHR are statistically significant at 5\% significance level. The study recommends that there is a need for increased Federal government support to banks in terms of policies that would encourage lending to the private sector in Nigeria.
\end{abstract}

Keywords: Bank credit, Private investment, OLS regression, cointegration, Granger causality.

JEL classification: B22, B26, E44, E50, G21, N27.

\section{Introduction}

Banks have a strategic role to play in national development as a result of their basic function as financial intermediaries, saving mobilization especially from the surplus to sectors that are deficient. Bank credit plays an important role in the funding of capital investment in

\footnotetext{
* Corresponding author
} 
Nigeria. The corporate finance structure in Nigeria has been characterized by strong bank-lending relationships. The size of the banking sectors' assets relative to GDP determines its strategic role it plays in the economy. Banks' assets are predominately loans and the ease with which companies can access credit is an appropriate measure for the financial sector's contribution to economic growth, which implies that the failure of the banking system brings host implications for the real economy. Sichei and Njenga (2012) stated that monetary policy is transmitted to the real economy through different channels which are collectively known as monetary policy transmission mechanisms. There are four channels of monetary policy transmissions in any modern economy; interest rate channel, credit channel (balance-sheet and bank-lending channels), exchange rate channel and other asset (equity and real estate) prices channel. The interest rate channel is the basic transmission mechanism. Changes in the average interest rates will also have cash flow effects on borrowers and lenders (Sichei and Njenga, 2012).

Banks play a pivotal role in the credit transmission channel of the economy, developed or developing, liberalised or centrally controlled. By its very nature, banking is an attempt to manage multiple and seemingly opposing needs. Banks accept deposits, by assuring savers that their deposits are liquid and secured. In recognition of the fact that a well-equipped and capitalized bank would go along in strengthening the banking sector, the CBN raised the minimum capitalization for banks from N2billion (naira) to N25 billionin 2004. The recapitalization of the country's banking sector was aimed at establishing a diversified, strong and reliable banking sector which will ensure the safety of the depositors' money, play active developmental roles in Nigerian economy, and be competent and competitive in the African regional and global financial system (Soludo, 2007).

\subsection{Statement of the problem}

In Nigeria, the problem of mobilizing savings and deposits has always been the bane of economic growth and development. Savings and investment are very minimal in Nigeria due to high inflation and currency devaluations (Uremadu, 2007). As financial resources are a very vital factor in economic development, its mobilization will lead to increased capital formation. Capital formation or gross domestic investment (GDI) requires the release of domestic goods and services for real asset investment or the import of resources from outside or, as it is usually the case, a combination of the two (Uremadu, 2006). The financial mobilization problem is closely linked with savings problems, and developing countries are commonly characterized by a low rate of domestic savings. Nonetheless, gross domestic savings is still relatively reasonable in most Least Developing Countries (LDCs), but the efficiency in translating accumulated savings into productive investments is lacking. Thus the Private sector continues to face challenges in terms of asses to credit in the face of growth of the financial sector and interventions by the nation's apex body, the Central Bank of Nigeria (CBN) in boosting liquidity. The CBN also introduced a low interest policy in order to stimulate lending to the private sector. But the deposit money banks are still reluctant to extend credit mainly due to the high risk perception in the market. The question this study tends to answer is therefore stated as follows: Does bank credit impact on private investment in Nigeria? What is the direction of causality between bank credit, other monetary policy variables and private investment growth in Nigeria?

\subsection{Objectives of the study}

The broad objective of this study is to investigate the link between banks credit and private sector investment in Nigeria. The specific objectives are:

a. To determine the impact of other macroeconomic variables on private investment in Nigeria

b. To determine the direction of causality between bank credit, macroeconomic variables and private investment growth in Nigeria 
c. To proffer measures aimed at improving access to bank credit facilities by the private sector in the country.

\subsection{Hypothesis of the study}

The research hypotheses that would guide this study is therefore stated as follows:

i. There is no link between banks credit and private sector investment growth in Nigeria

ii. There is no link between other macroeconomic variables and private investment growth in Nigeria

iii. There is no direction of causality between banks credit, macroeconomic variables and private investment in Nigeria

\subsection{Scope of the study}

This study covers the period from 1980 to 2014. The choice of this particular period is motivated by the availability of data.

\section{Literature review}

The role of financial services sector which involves deposit mobilization and credit supplies to the economic units of the polity is widely acknowledged in Literature.Some of these works that concern environmental factors that affect credit availability to private sector investment and the overall impact on the economy will be reviewed. Traditionally, there are four key channels of monetary policy transmission mechanism which include interest rate, credit aggregates, asset prices and exchange rate channels. Bernanke and Gertler (1995) noted interest rate channel as the dominant transmission mechanism of monetary policy. According the authors, an expansionary monetary policy is expected to lead to a lowering cost of loanable funds, which would lead to a rise in investment and consumption demand and equally be reflected in aggregate output and prices. Mohan (2008) stated that a fifth channel -expectation- has taken a prominent role in the conduct of forward looking monetary policy as a result of its influence on the traditional four channels. According to the author, the interaction between short and long run real rates is widely acknowledged to move from the expectational hypothesis of the term structure of interest rates. The expectations channel of monetary policy states that the vies of economic agents about future shocks to the economy as the central bank's reactions can impact the variables that are determined in a forward looking approach(Mohan, 2008). Also, Knoop (2008) identifies two important features of the above mentioned channels of monetary policy transmission. First, these channels are not mutually exclusive. This means monetary policy can operate through all the channels at the same time. Second, each of these channels operates through their effect on aggregate demand and investment. When the central bank increases money supply and lowers interest rates, the profits and cash flows of borrowers increase and increase in money supply also improves the financial position of lenders by increasing liquidity and asset prices. Lenders respond to these improvements by reducing their lending rates as well as lowering other costs of credit intermediation. These lower costs of credit intermediation increase credit and spur consumption and investment.

\subsection{Bank level environment}

According to Love and Mylenko (2003), in Sub-Saharan Africa (SSA), a sharp rise in banks' investment in government securities has been recorded. As a result, commercial banks hold a very large part of their domestic assets in the form of government securities. The authors further argued that the increased return on government paper and bank bills provides banks with an alternative opportunity for high return low risk investment. From the supply side, securities issuance was increased through government borrowing to finance fiscal deficits. 
In SSA, banks plays an important role as result of their dominance in the financial systems and due to limitations of informal finance. The extent of banks' lending especially to Small and Medium Scale Enterprises (SMEs) depend on a range of country and bank specific factors (Beck, Demirgüç - Kunt and Martinez Peria, 2011). The factors according to the authors, include macroeconomic environment, the legal and regulatory framework, the state of the financial sector infrastructure, banks internal limitations in terms of capacity utilization and technology. Other factors include SME specific factors especially the SME landscape in terms of size, number and focus of operation. The SMEs are typically more credit constrained in SSA than large firms and this affects their growth (Beck et al, 2011).

A cross-country study on the drivers of bank financing according to Berg and Fuchs (2013) indicate that the share of lending to the SMEs in the overall portfolios of banks varies between ten to twenty percent. The authors noted that banks in Kenya, Rwanda and Tanzania are more involved with SMEs in terms of the share loan book moving to the SMEs than banks in Nigeria and South Africa. The most important contributing factors to banks' lending include the structure and size of the economy, the extent of Government borrowing, the degree of innovation as regards SME lending; and the state of the financial sector infrastructure as well as the enabling environment including Government support programmes (Berg and Fuchs, 2013).

\subsection{Investment in Nigeria}

From 2004, investment in the Nigerian economy has continuously witnessed a decline which has fallen below any other level of loss ever recorded in this sector since independence. With as low as N1921.2 million in 2005 to as drastically low as N114,484.4 million in the year 2008 , the levels of domestic investment in the Nigeria economy was about $145 \%$ lower than 2004 level (Donwa and Agbontaen, 2010). The authors noted that the level of technical know-how is still very low while supply of infrastructural facilities remains inadequate. These evidence of inconsistencies in both policy prescription and prudent fiscal measures have resulted to huge capital flights. The instability in the polity have led to decline in the level of investment activities (Donwa and Agbontaen, 2010). However, in 2014 as result of rapidly growing contribution to the Nigerian economy from sectors such as telecommunication, banking and film industry, the Government rebased its Gross Domestic Product (GDP) to $\$ 510$ billion (United States Dollars). Thus making the economy one of the largest in Sub-Saharan Africa.

\subsection{Empirical review}

Sinevičienè (2015) examines relationship between government expenditure and private investment in the case of small open economies using cross-correlations and Granger causality tests on time series data of Bulgaria, Estonia, Latvia, Lithuania and Slovenia from 1996 - 2012. The results show that impact of public spending increase on private investment is very weak except in the case of Bulgaria. The study also notes that the impact of private investment increase on public spending is very different in analyzed countries.

Omorokunwa and Ikponmwosa (2014) investigate the dynamic relationship between exchange rate volatility and foreign private investment in Nigeria from 1980 to 2011 . Using Error Correction Model (ECM) techniques, the result shows that exchange rate shows negative effect on Foreign Direct Investment (FDI) to Nigeria. The result shows a strong positive effect on portfolio in the long run.

Zardashty (2014) analyze the impacts of real exchange rate on private sector investment in Iran from 1961-2008 using an EGARCH model. The results indicate that the index of real exchange rate has a negative effect on private investment, GDP ratio, and imports of capital commodity. The result equally indicates that inflation have negative effects on private investment to GDP ratio. 
Oyieke (2011) examines the relationship between public investment and it's financing on private sector investment in Kenya from 1964 to 2006. Using an error correction framework and time series data for the fiscal years 1964-2006, the study indicates that agricultural investment has a significant positive effect on private investment and domestic debt has a negative effect.

Rahila, Rehmat and Zakir (2010) examine long run and short run relationship between private investment, savings, real interest rate on Bank deposits and Bank Credit to the private sector in Pakistan for the period 1973 to 2007. Applying ARDL Bounds Testing Approach, the results show that Private Investment is positively affected by Savings, Real interest rate on bank deposits, Bank credit to private sector and Public investment in the long run.

\section{Methodology of the research}

\subsection{Sources of data}

The research utilizes data generated from the Central Bank of Nigeria statistical bulletin on private sector investment, data on total bank savings, interest rate, exchange rate, trade openness, government capital expenditure and total bank credit to private sector from 1980-2014.

\subsection{Data analysis method}

The study employed OLS regression for the data analysis. The private investment is the dependent variable, while, banks credit, trade openness, capital expenditure, interest rate, exchange rate and bank saving, are the independent variables. The model for the impact of banks credit on private investment in Nigeria could be stated as follows:

\subsection{Model specification}

INVEST $=($ CRPRIVAT, OPEN, CAP, INTR, EXCHR, BSAVING)

SET DEFINITION

INVEST = private investment

CRPRIVAT $=$ Banks credit to the private sector

OPEN = Trade openness

$\mathrm{CAP}=$ Federal capital expenditure

INTR = Interest rate

$\mathrm{EXCHR}=$ Exchange rate

BSAING = Total bank saving

Assuming a linear relationship between the dependent variable and independent variables, and using the multiple regression model can be specified as follows:

INVEST $=\alpha_{0}+\alpha_{1} \mathrm{CRPRIVAT}+\alpha_{2} \mathrm{OPEN}+\alpha_{3} \mathrm{CAP}+\alpha_{4} \mathrm{INTR}+\alpha_{5} \mathrm{EXCHR}+\alpha_{6} \mathrm{BSAVING}+\mu_{\mathrm{t}}$

where $\mu_{\mathrm{t}}=$ Error term

\subsection{Estimation Procedures \\ Unit root test}

To test for stationarity is done using the Augmented Dickey Fuller test (ADF). The ADF test equation is specified as follows:

$$
\Delta \widehat{u}_{t}=\beta \widehat{u}_{t-1}+\sum_{i=1}^{k} \Delta \widehat{u}_{t-1}+\varepsilon_{t}
$$




\section{Cointegration test}

When a linear combination of variables that are I(1) produces a stationary series, then the variables may need to be cointegrated. This means that a long-run relationship may exist among them, which connotes that they may wander from one another in the short-run but in the long-run they will move together. To establish whether long-run relationship exists among the variables or not, cointegration tests are conducted by using the multivariate procedure developed by Johansen (1988) and Johansen and Juselius (1990).

\section{Granger causality test procedure}

In order to determine the direction of causality between the bank credit variable and investment in Nigeria, a granger causality test is carried out. In order to examine the Granger causal relationships between the variables under examination, we used the estimated model in the previous section. F -statistic was used as a testing criterion. The procedure is therefore stated as follows:

$$
\begin{aligned}
& I_{t}=\alpha_{0}+\sum_{i=1}^{k_{1}} \alpha_{i} I_{t-1}+\sum_{i=1}^{k_{2}} \beta_{i} X_{t=1}+\sum_{t} \\
& \mathrm{X}_{\mathrm{t}}=\Upsilon_{0}+\sum_{i=1}^{k_{3}} \Upsilon_{i} I_{t=1}+\sum_{i=1}^{k_{4}} \lambda_{i} X_{t=1}+\omega_{t}
\end{aligned}
$$

where

$\mathrm{X}=$ an indicator of banks credit,

$I=$ investment

$\mathrm{t}=$ current value of investment

$\mathrm{t}-1$ lagged value of investment

\section{Analysis of the findings}

\subsection{Descriptive Statistics}

The results of the descriptive statistics conducted which include, INVEST, CRPRIVAT, OPEN, CAP, INTR, EXCHR and BSAVING are shown in the below:

Table 1: Descriptive statistics

\begin{tabular}{|l|l|l|l|l|l|l|l|}
\hline & INVEST & CRPRIVAT & OPEN & CAP & INTR & EXCHR & BSAVING \\
\hline Mean & 2427052. & 1040624. & 70.36962 & 143407.5 & 18.05390 & 68.85175 & 350.9147 \\
\hline Median & 346043.2 & 87744.30 & 80.90000 & 34052.10 & 18.63750 & 21.96860 & 30.36395 \\
\hline Maximum & 10206087 & 10206087 & 97.30000 & 498027.6 & 36.09000 & 158.5526 & 3330.289 \\
\hline Minimum & 9670.500 & 9670.500 & 27.80000 & 82.25781 & 6.600000 & 0.610000 & -0.583900 \\
\hline Std. Dev. & 3724419. & 2305185. & 19.26649 & 167971.9 & 7.084791 & .47515 & 698.0429 \\
\hline Skewness & 1.276122 & 2.923334 & 1.102383 & 0.660895 & 0.425249 & 0.198392 & 2.796133 \\
\hline Kurtosis & 2.830668 & 10.80579 & 2.850128 & 1.791442 & 2.745555 & 1.216575 & 11.21345 \\
\hline Jarque-Bera & 9.268722 & 134.7447 & 6.918227 & 4.544301 & 1.116461 & 4.728894 & 139.8734 \\
\hline Probability & 0.009712 & 0.000000 & 0.031458 & 0.103090 & 0.572221 & 0.094001 & 0.000000 \\
\hline Observations & 34 & 34 & 34 & 34 & 34 & 34 & 34 \\
\hline
\end{tabular}

Source: Author's computation from Eviews result

From the result above, the probabilities of Jarque-Bera test for normality for six of the variables indicates values above $5 \%$ significant level. The result also indicates that all the variables have a positive mean values which ranges from 2427052 to 18.05390 with 34 
observations. The highest standard deviation of 3724419 is recorded by INVEST while the least standard deviation of 7.084791 is recorded by INTR. Notwithstanding the deviations from the mean, the relationships among the studied variables depicted in the model were tested using correlation test procedure and the result presented in the table below:

\subsection{Correlation}

In the correlation test, we examined the variables to ascertain the degree of relationships that exist between the independent variables and the dependent variable. For the variables under consideration, the values obtained are as follows:

Table 2: Correlation matrix

\begin{tabular}{|l|l|l|l|l|l|l|l|}
\hline & INVEST & CRPRIVAT & OPEN & CAP & INTR & EXCHR & BSAVING \\
\hline INVEST & 1.000000 & 0.448077 & 0.409235 & -0.145546 & -0.367984 & 0.787568 & 0.762282 \\
\hline CRPRIVAT & 0.448077 & 1.000000 & 0.275407 & 0.289112 & 0.093089 & 0.437784 & 0.444428 \\
\hline OPEN & 0.409235 & 0.275407 & 1.000000 & 0.442683 & 0.498329 & 0.623284 & 0.316356 \\
\hline CAP & -0.145546 & 0.289112 & 0.442683 & 1.000000 & 0.402156 & 0.377976 & -0.063337 \\
\hline INTR & -0.367984 & 0.093089 & 0.498329 & 0.402156 & 1.000000 & -0.047955 & -0.243987 \\
\hline EXCHR & 0.787568 & 0.437784 & 0.623284 & 0.377976 & -0.047955 & 1.000000 & 0.613217 \\
\hline BSAVING & 0.762282 & 0.444428 & 0.316356 & -0.063337 & -0.243987 & 0.613217 & 1.000000 \\
\hline
\end{tabular}

Source: Author's computation from Eviews result

The correlation result shows that four of our focal variables, CRPRIVAT, OPEN, EXCHR and BSAVING have positive relationships with the INVEST. The relationships are actually strong at $44 \%, 40 \%, 78 \%$, and $76 \%$, while CAP $(-14 \%)$ and INTR $(-36 \%)$ respectively.

\subsection{The OLS Regression}

From the table, the coefficients of the variables, CRPRIVAT, OPEN, EXCHR and BSAVING show positive signs which indicate their positive relationship to the level of investments in Nigeria during the period under review.

Table 3: Regression result

\begin{tabular}{|l|l|l|l|l|}
\hline \multicolumn{2}{|l|}{ Dependent variable: INVEST } & \multicolumn{5}{l}{} \\
\hline Variable & Coefficient & Std. Error & t-Statistic & Prob. \\
\hline C & -146897.5 & 729526.4 & -0.201360 & 0.8419 \\
\hline CRPRIVAT & 0.340295 & 0.093053 & 3.657012 & 0.0011 \\
\hline OPEN & 54408.56 & 16154.23 & 3.368070 & 0.0023 \\
\hline CAP & -9.548022 & 1.379365 & -6.922043 & 0.0000 \\
\hline INTR & -157011.6 & 37408.76 & -4.197188 & 0.0003 \\
\hline EXCHR & 34655.79 & 5040.409 & 6.875590 & 0.0000 \\
\hline BSAVING & 595.4113 & 379.1764 & 1.570275 & 0.1280 \\
\hline R-squared & 0.939701 & Mean dependent var & 2427052. & \\
\hline Adjusted R-squared & 0.926301 & S.D. dependent var & 3724419. & \\
\hline S.E. of regression & 1011087. & Akaike info criterion & 30.67219 & \\
\hline Sum squared resid & $2.76 \mathrm{E}+13$ & Schwarz criterion & 30.98644 & \\
\hline Log likelihood & -514.4273 & F-statistic & 70.12806 & \\
\hline Durbin-Watson stat & 1.759484 & Prob(F-statistic) & 0.000000 & \\
\hline
\end{tabular}

Source: Author's computation from Eviews result 
The positive effect of exchange rate conforms to Omorokunwa and Ikponmwosa (2014) findings on the dynamic relationship between exchange rate volatility and foreign private investment in Nigeria which shows a strong positive effect on portfolio investment in the long run. The positive coefficient of the BSAVING is in line with Olweny and Chiluwe (2012) study of interaction existing between monetary policy and private sector investment in Kenya that money supply and domestic savings have positive relationship with private sector investment. The positive effect of credit equally show that as saving increases, banks continues to expand their lending activities to the private sectors. The availability of credit in an economy due to high level of saving attracts foreign investment into the country. It could also be seen that the Nigerian economy operated high degree of openness; the implication is that it allowed foreign participation in the economy. Also the coefficient of CAP and INTR indicates negative signs which imply that the variables relationship with the level of investment in the economy during the period under review is negative. The result conforms to findings of Sinevičienè (2015) in a study of the relationship between government expenditure and private investment in the case of small open economies, that impact of public spending increase on private investment is very weak. The low level of interest rate means that there is access to loanable funds which increases production capacities in the economy. The marginal propensity to save in an economy would always decline whenever the interest rate becomes low but high level of saving increases investment activities in the economy. Statistically, five of the variables which includes, CRPRIVAT, OPE, CAP, INTR and EXCHR show values that are greater than positive and negative two. This shows that the variables are statistically significant at $5 \%$ significance level. The $\mathrm{F}$ - tabulated shows that the overall estimate of the regression has a good fit and is statistically significant. The $R^{2}$ (R-squared adjusted) shows that the independent variables explain the dependent variable to the tune of $92 \%$. Also the Durbin Watson (DW) statistics DW $=1.759484$, which is greater than the $\mathrm{R}^{2}$ shows that the overall regression is statistically significance.

\subsection{Unit root test}

In literature, most time series variables are non-stationary and using non-stationary variables in the model might lead to spurious regression (Granger 1969). The first or second differenced terms of most variables will usually be stationary (Ramanathan 1992). Using the Augmented Dickey Fuller (ADF) test for the unit root for the levels as follows:

Table 4: The stationarity test result

\begin{tabular}{|c|c|c|c|}
\hline \multicolumn{4}{|c|}{ Augmented Dickey Fuller ADF test } \\
\hline Variable & First difference & probability & Order of integration \\
\hline INVEST & -2.576909 & 0.0151 & $\mathrm{I}(1)$ \\
\hline CRPRIVAT & -4.753276 & 0.0000 & $\mathrm{I}(1)$ \\
\hline OPEN & -4.115795 & 0.0003 & $\mathrm{I}(1)$ \\
\hline CAP & -3.712497 & 0.0008 & $\mathrm{I}(1)$ \\
\hline INTR & -6.307989 & 0.0000 & $\mathrm{I}(1)$ \\
\hline EXCHR & -3.350230 & 0.0022 & $\mathrm{I}(1)$ \\
\hline BSAVING & -4.281679 & 0.0002 & $\mathrm{I}(1)$ \\
\hline
\end{tabular}

Source: Author's computation from Eviews result

The stationarity test result indicates that all the variables under consideration are stationary and integrated of order one at $5 \%$ level of significance. A cointegration test is therefore, conducted. 


\subsection{Cointegration}

The Johansen hypothesized cointegration was carried out to determine the number of stationary long-run relationship among the variables included in the study. It offers two tests, the trace test and the Eigen value test, with a view to identify the number of cointegrating relationships. The results of the conducted Johansen tests for co-integration amongst the variables is specifies in table below:

Table 5: Cointegration test

\begin{tabular}{|c|c|c|c|c|}
\hline Eigenvalue & Likelihood Ratio & $\begin{array}{l}5 \text { Percent } \\
\text { Critical Value }\end{array}$ & $\begin{array}{l}1 \text { Percent } \\
\text { Critical Value }\end{array}$ & $\begin{array}{l}\text { Hypothesized } \\
\text { No. of CE(s) }\end{array}$ \\
\hline 0.982213 & 310.8333 & 109.99 & 119.80 & None ${ }^{* *}$ \\
\hline 0.935582 & 181.8961 & 82.49 & 90.45 & At most $1^{* *}$ \\
\hline 0.683736 & 94.14054 & 59.46 & 66.52 & At most $2^{* *}$ \\
\hline 0.596211 & 57.30289 & 39.89 & 45.58 & At most $3^{* *}$ \\
\hline 0.434343 & 28.28329 & 24.31 & 29.75 & At most $4^{*}$ \\
\hline 0.265322 & 10.05072 & 12.53 & 16.31 & At most 5 \\
\hline 0.005745 & 0.184374 & 3.84 & 6.51 & At most 6 \\
\hline \multicolumn{5}{|c|}{$\left.{ }^{*}{ }^{* *}\right)$ denotes rejection of the hypothesis at $5 \%(1 \%)$ significance level } \\
\hline \multicolumn{5}{|c|}{ L.R. test indicates 5 cointegrating equation(s) at $5 \%$ significance level } \\
\hline
\end{tabular}

Source: Author's computation from Eviews result

From the table above, the trace likelihood ratio results point out that the null hypothesis of no cointegration among the variables is rejected in favour of the alternative hypothesis up to five cointegrating equations at $5 \%$ significant level because their values exceed the critical values. This means there are at most five cointegrating equations, which implies that a unique long-run relationship exists among the variables and the coefficients of estimated regression can be taken as equilibrium values. It can thus be stated that there exists a positive long run relationship between banking sector credit and private investment in the Nigerian economy during the period under review.

\subsection{Granger causality test}

The Granger causality procedure employed in this study for testing statistical causality between the credit, saving interest and investment is developed by C.W.J. Granger in 1969. In order to examine the Granger causal relationships between the variables under examination, we used the estimated model in the previous section. $\mathrm{F}$-statistic was used as a testing criterion. The results relating to the existence of Granger causal relationships between the variables are presented in the table below:

Table 6: Granger causality test

\begin{tabular}{|l|l|l|l|}
\hline Null Hypothesis: & Obs & F-Statistic & Probability \\
\hline CRPRIVAT does not Granger Cause INVEST & 33 & 7.62803 & 0.00227 \\
INVEST does not Granger Cause CRPRIVAT & & 20.3683 & $3.5 \mathrm{E}-06$ \\
\hline OPEN does not Granger Cause INVEST & 33 & 0.49319 & 0.61588 \\
INVEST does not Granger Cause OPEN & & 0.00852 & 0.99152 \\
\hline CAP does not Granger Cause INVEST & 33 & 4.03809 & 0.02878 \\
INVEST does not Granger Cause CAP & & 9.98334 & 0.00053 \\
\hline INTR does not Granger Cause INVEST & 33 & 0.51800 & 0.60131 \\
INVEST does not Granger Cause INTR & & 1.96098 & 0.15957 \\
\hline EXCHR does not Granger Cause INVEST & 33 & 4.44304 & 0.02109 \\
INVEST does not Granger Cause EXCHR & & 0.10543 & 0.90029 \\
\hline BSAVING does not Granger Cause INVEST & 32 & 0.28446 & 0.75465 \\
INVEST does not Granger Cause BSAVING & & 7.64894 & 0.00233 \\
\hline
\end{tabular}

Source: Author's computation from Eviews result 
The results given above suggest that there exists a bi-directional causality between banks credit and private investment. There is no direction of causality between trade openness and private investment. The study shows that there is bi-directional causality between private investment and capital expenditure. The result table indicates no direction of causality between interest rate and private investment. The result equally indicates that there is a uni-directional causality from exchange rate to private investment. A uni-directional causality exists from private investment to bank saving.

\section{Conclusion}

It has been noted that credit plays an important role in the funding of new investments in Nigeria. Monetary policy is transmitted to the real economy through different channels which are collectively known as monetary policy transmission mechanisms. The OLS regression result obtained shows that the coefficients of the variables, CRPRIVAT, OPEN, EXCHR and BSAVING show positive signs which indicates their positive relationship to the level of investments in Nigeria during the period under review. Also the coefficient of CAP and INTR indicates negative signs which imply that the variables relationship with the level of investment in the economy during the period under review is negative. Statistically, the t-statistic result shows that five of the variables which includes, CRPRIVAT, OPE, CAP, INTR and EXCHR are statistically significant at 5\% significance level. The stationarity test result obtained indicates that all the variables under consideration are stationary and integrated of order one at $5 \%$ level of significance. The Johansen hypothesized cointegration test result shows that the trace likelihood ratio results point out that the null hypothesis of no cointegration among the variables is rejected in favour of the alternative hypothesis up to five cointegrating equations at $5 \%$ significant level. The Granger causality procedure conducted indicates that there exists a bi-directional causality between banks credit and private investment; also, there is bi-directional causality between private investment and capital expenditure. While a uni-directional causality exists from exchange rate to private investment.

Furthermore, the positive relationship between bank credit to the private sector variable, (CRPRIVAT) and the private investment in Nigeria during the period under review ensures that the major objective of the study which is to investigate the link between banks credit and private sector investment in Nigeria has been achieved; and as result, we accept the hypothesis that there is a link between banks credit and private sector investment growth in Nigeria. The study therefore recommends that there is a need for increased Federal government support to banks in terms of policies that would encourage lending to private sector in Nigeria. Banks should place more emphasis on human capacity building to ensure funding of viable projects for enhanced economic growth and development. The Central Bank should focus on market driven interest rate regime in order to encourage savings as well as boosting investment activities in the country.

\section{References}

Beck, T., Demirgüç -Kunt, A., Martinez Peria, M. (2011). 'Bank financing for SMEs: Evidence across countries and bank-ownership types'. Journal of Financial Services, Vol. 39, pp. 35-54.

Berg, G., Fuchs, M. (2013). 'Bank Financing of SMEs in Five Sub-Saharan African Countries: The Role of Competition, Innovation, and the Government', The World Bank Policy Research Working Paper 6563. 
Bernanke, B., Gertler, M. (1995). 'Inside the black box: the credit channel of monetary policy transmission', Journal of Economic Perspectives, vol. 9, no. 4. Available from: http://www.nber.org/papers/w5146. [02.02.2017]

Donwa, P., Agbontaen, O.O. (2010). 'Trends and dynamics of the determinants of investment in Nigeria', International Review of Business Research Papers, vol. 6, no. 6, pp. $153-163$.

Granger, C. W. J. (1969). 'Investigating Causal Relationship by Econometric models and Gross-spectral Methods', Econometrics, vol. 37, no 3, pp. 242-238.

Johansen, S. (1988). 'Statistical analysis of cointegration vectors', Journal of Economic Dynamics and Control, vol. 12, pp. 231-54.

Johansen, S., Juselius, K. (1990). 'Maximum likelihood estimation and inference on cointegration with applications to the demand for money', Oxf. Bull. Econ. Stat. vol. 52, pp. 169-210.

Knoop, T. (2008). Modern Financial Macroeconomics: Panics, Crashes, and Crises, Wiley Blackwell publishing.

Love, I., Mylenko, N. (2003). 'Credit reporting and financing constraints', World Bank Policy Research, Working Paper No. 3142.

Mohan, R. (2008). 'Monetary policy transmission in India', BIS working papers no 35. Available from: http://www.bis.org/publ/bppdf/bispap35m.pdf. [02.02.2017]

Olweny, T., Chiluwe, M. (2012). 'The Effect of Monetary Policy on Private Sector Investment in Kenya', Journal of Applied Finance \& Banking, vol. 2, no. 2, pp. 239-287.

Omorokunwa, O.G., Ikponmwosa, N. (2014). 'Exchange Rate Volatility and Foreign Private Investment in Nigeria', Asian Journal of Business Management, vol. 6, no. 4, pp. 146-154.

Oyieke, S. O. (2011). 'Government Capital Spending and Financing and its Impact on Private Investment in Kenya: 1964-2006', African Economic Research Consortium, Nairobi, Research Paper No. 236.

Sacerdoti, E. (2005). 'Access to Bank Credit in Sub-Saharan Africa: Key Issues and Reform Strategies', International Monetary Fund, Monetary and Financial Systems Department, Working Paper WP/05/166.

Ramanathan, R. (1992). Introductory Econometrics with Applications, Second Edition. Harcourt New York, Brace Jovanovich.

Sichei, M.M., Njenga G. (2012). 'Does Bank Lending Channel Exist in Kenya: Bank Level Panel Data Analysis', African Economic Research Consortium Research Paper 249. Available online

from

http://aercafrica.org/index.php/publications/view document/346-does-bank-lending-channe l-exist-in-kenya-bank-level-panel-data-analysis. [02.02.2017]

Sinevičienè L.(2015). 'Testing the Relationship between Government Expenditure and Private Investment: The Case of Small Open Economies', Journal of Economics, Business and Management, vol. 3, no. 6. pp. 1-2.

Soludo, C. C. (2007). 'Monetary and Financial Sector Developments in Nigeria'; available from CBN website: www.cenbank.org. [02.02.2017]

Rahila, M., Rehmat U. A., Zakir, H. (2010). 'Investment, Savings, Interest Rate and Bank Credit to the Private Sector Nexus in Pakistan', International Journal of Marketing Studies, vol.2, no.1, pp. 1-2.

Uremadu, S.O. (2007). 'Core Determinants of Financial Savings in Nigeria: An Empirical Analysis for National Monetary Policy Formulation', International Review of Business Research Papers, pp. 356-367.

Uremadu, S.O.(2006). 'The Impact of Real Interest Rate on Savings Mobilization in Nigeria'; An Unpublished Ph.D thesis, cited in Uremadu, S.O.(2011) 'Foreign Direct Investment, Liquidity and Real Country Growth Evidence From Nigeria', International Review of Business Research Papers, vol. 7, no. 3, pp. 170 -193. 
Zardashty, G. R. (2014). 'The impact of real exchange rate uncertainty on private investment in Iran', Kuwait Chapter of Arabian Journal of Business and Management Review, vol.3, no.10, pp.1-2.

\section{Bio-note}

Ugwu Ephraim is currently an Assistant Lecturer at the Federal University, Oye Ekiti (FUOYE), Ekiti State, Nigeria. He was previously a Project Manager at the Innovation and Research Centre, FUOYE. He studied Economics at the University of Nigeria, Nsukka and graduated with Bachelor of Science degree in Economics with Second Class Upper division and a Master of Science degree in Economics (Public Finance). As a researcher, Mr. Ephraim's interest is focused on issues relating to public finance and developments especially in the developing economies.

Okoh Johnson holds a PhD in Banking and Finance from Nnamdi Azikiwe University, Awka Anambra State, Nigeria. He has a master's degree in Banking and Finance and holds a B.Sc in Accountancy (2nd Class Upper Division). He had over 10years practical banking experience before he joined academics in 2012. He lectures Accounting, Banking \& Finance in the University.

Mbah Stella is a Lecturer 11 with the Department of Economic and Development Studies in Federal University Oye-Ekiti, Ekiti State, Nigeria. She holds a master's degree in Economics and her research field is in Development Economics. 